\title{
Identification of Novel Candidate Genes and Variants for Hearing Loss and Temporal Bone Anomalies
}

\author{
Regie Lyn P. Santos-Cortez ${ }^{1,2,3, *}$, Talitha Karisse L. Yarza ${ }^{3,4}$, Tori C. Bootpetch ${ }^{1}$, Ma. Leah C. Tantoco ${ }^{3,4,5}$, \\ Karen L. Mohlke ${ }^{6}$, Teresa Luisa G. Cruz ${ }^{3,5}$, Mary Ellen Chiong Perez ${ }^{7}$, Abner L. Chan ${ }^{3,5}$, Nanette R. Lee ${ }^{8}$, \\ Celina Ann M. Tobias-Grasso ${ }^{9}$, Maria Rina T. Reyes-Quintos ${ }^{3,4,5}$, Eva Maria Cutiongco-de la Paz ${ }^{10,11}$ \\ and Charlotte M. Chiong ${ }^{3,4,5,12, *}$
}

check for updates

Citation: Santos-Cortez, R.L.P.; Yarza, T.K.L.; Bootpetch, T.C.; Tantoco, M..L.C.; Mohlke, K.L.; Cruz, T.L.G.; Chiong Perez, M.E.; Chan, A.L.; Lee, N.R.;

Tobias-Grasso, C.A.M.; et al. Identification of Novel Candidate Genes and Variants for Hearing Loss and Temporal Bone Anomalies. Genes 2021, 12, 566. https://doi.org/ 10.3390/genes12040566

Academic Editor:

Selvarangan Ponnazhagan

Received: 26 February 2021

Accepted: 8 April 2021

Published: 13 April 2021

Publisher's Note: MDPI stays neutral with regard to jurisdictional claims in published maps and institutional affiliations.

Copyright: (C) 2021 by the authors Licensee MDPI, Basel, Switzerland This article is an open access article distributed under the terms and conditions of the Creative Commons Attribution (CC BY) license (https:// creativecommons.org/licenses/by/ $4.0 /)$.
1 Department of Otolaryngology-Head and Neck Surgery, School of Medicine, University of Colorado Anschutz Medical Campus, Aurora, CO 80045, USA; tori.bootpetch@cuanschutz.edu

2 Center for Children's Surgery, Children's Hospital Colorado, Aurora, CO 80045, USA

3 Philippine National Ear Institute, University of the Philippines (UP) Manila-National Institutes of Health (NIH), Manila 1000, Philippines; tlyarza@up.edu.ph (T.K.L.Y.); mlct19976@hotmail.com (M.L.C.T.); tgcruz1@up.edu.ph (T.L.G.C.); alchan@up.edu.ph (A.L.C.); mtreyesquintos@up.edu.ph (M.R.T.R.-Q.)

4 Newborn Hearing Screening Reference Center, UP Manila-NIH, Manila 1000, Philippines

5 Department of Otorhinolaryngology, UP Manila College of Medicine-Philippine General Hospital (UP-PGH), Manila 1000, Philippines

6 Department of Genetics, University of North Carolina, Chapel Hill, NC 27599, USA; mohlke@med.unc.edu

7 Department of Anesthesiology, UP Manila College of Medicine, Manila 1000, Philippines; mcperez6@up.edu.ph

8 Office of Population Studies and Department of Anthropology, Sociology and History, University of San Carlos, Cebu City 6000, Philippines; nanette_rlee@yahoo.com

9 MED-EL, 6020 Innsbruck, Austria; celina.tobias-grasso@med-el.com

10 Institute of Human Genetics, UP Manila-NIH, Manila 1000, Philippines; eccutiongcodelapaz@up.edu.ph

11 Philippine Genome Center, UP Diliman Campus, Quezon City 1101, Philippines

12 UP Manila College of Medicine, Manila 1000, Philippines

* Correspondence: regie.santos-cortez@cuanschutz.edu; (R.L.P.S.-C.); cmchiong@up.edu.ph (C.M.C.)

Abstract: Background: Hearing loss remains an important global health problem that is potentially addressed through early identification of a genetic etiology, which helps to predict outcomes of hearing rehabilitation such as cochlear implantation and also to mitigate the long-term effects of comorbidities. The identification of variants for hearing loss and detailed descriptions of clinical phenotypes in patients from various populations are needed to improve the utility of clinical genetic screening for hearing loss. Methods: Clinical and exome data from 15 children with hearing loss were reviewed. Standard tools for annotating variants were used and rare, putatively deleterious variants were selected from the exome data. Results: In 15 children, 21 rare damaging variants in 17 genes were identified, including: 14 known hearing loss or neurodevelopmental genes, 11 of which had novel variants; and three candidate genes IST1, CBLN3 and GDPD5, two of which were identified in children with both hearing loss and enlarged vestibular aqueducts. Patients with variants within IST1 and $M Y O 18 B$ had poorer outcomes after cochlear implantation. Conclusion: Our findings highlight the importance of identifying novel variants and genes in ethnic groups that are understudied for hearing loss.

Keywords: anomalies; $C B L N 3$; cochlear implant; enlarged vestibular aqueduct; GDPD5; genetic testing; hearing loss; inner ear; IST1; malformations; temporal bone

\section{Introduction}

Hearing loss remains a public health burden worldwide, with global measures of the effects of hearing disability remaining steady over the past three decades [1]. With the use of sequencing technologies in the clinical setting, identification of genetic variants that predispose to congenital or early childhood hearing loss is becoming more accessible to a 
larger segment of the world population. When partnered with newborn hearing screening, massively parallel DNA sequencing holds the promise of identifying the genetic cause(s) of hearing loss at the earliest stage and can therefore guide the clinician in diagnosing and treating comorbidities, planning rehabilitative options such as hearing aids or cochlear implantation (CI), and when they become available, applying gene therapies [2,3]. Genetic hearing loss is a highly heterogeneous disease both in terms of clinical presentation and pathogenic DNA variants, which are usually rare and may lie within any one of hundreds of genes [2,4]. The identification of variants for hearing loss and their corresponding clinical profiles in patients from various populations will contribute to the large body of knowledge that is required to improve the utility of clinical genetic screening for hearing loss. A large community of clinicians and scientists continues to identify novel genes and variants for syndromic and nonsyndromic hearing loss. In the past two years alone, variants within novel hearing loss genes including SLC9A3R1, ANLN, FOXF2, TOP2B, PLS1, PISD, CLRN2, $A P 1 B 1, S C D 5$, GGPS1, SLC12A2, THOC1 and GREB1L were identified in patients of various ethnicities [5-22]. To date, some of these genes remain candidates that require replication in additional hearing loss families and patients $[6,9,14,19]$.

Compared to hundreds of known hearing loss genes, studies on the genetic causes of temporal bone malformations are limited, with only a few genes identified so far, to name a few: EVA and/or Mondini dysplasia and SLC26A4; superior semicircular canal dehiscence (SSCD) or posterior semicircular canal dehiscence (PSCD) and CDH23; and variable cochleovestibular anomalies in some patients with variants in GJB2, POU3F4, SOX10, CHD7, SIX1 and GREB1L [20-29]. Prior knowledge of temporal bone malformations is important not only to prepare the surgeon for potential complications during CI but also to prognosticate outcomes after surgery [29-31]. Because CI is performed as early as three months old, occurrence of temporal bone anomalies might also be predicted earlier if genetic testing is performed at neonatal stage.

We previously studied a cohort of Filipino patients with hearing loss requiring CI [32-34]. In this cohort, we identified variants in known hearing loss genes in half of the patients, including a recurrent variant $S L C 26 A 4$ c.706C $>$ G (p.Leu236Val) that was associated with bilaterally enlarged vestibular aqueducts (EVA) [32-34]. Of eleven patients with previously identified non-SLC26A4 variants, only three had inner ear anomalies, including: EVA in a patient with an EYA4 variant; and SSCD in one patient with a KCNQ4 variant, and in another patient with CHARGE syndrome due to a CHD7 variant [32,34]. On the other hand, of the genetically unsolved cases, $75 \%$ had temporal bone anomalies (Table 1) [33]. In this study, we reviewed the clinical and exome data of Filipino cochlear implantees and identified 12 novel variants in known genes for hearing loss and/or neurodevelopmental syndromes, as well as three candidate genes for hearing loss.

Table 1. Clinical data for 15 Filipino children with hearing loss requiring cochlear implants (CI).

\begin{tabular}{cccccc}
\hline ID & Age at CI (yr) & Sex & Temporal Bone Findings & Clinical History & Gene \\
\hline 1 & 3.95 & M & EVA, L & $\begin{array}{c}\text { Bilateral small choroidal } \\
\text { fissure cysts and a probable } \\
\text { neuroepithelial cyst or } \\
\text { prominent perivascular space } \\
\text { involving the right peri-atrial } \\
\text { white matter (MRI). }\end{array}$ \\
\hline 3 & 2.83 & $\mathrm{M}$ & $\begin{array}{c}\text { Malformed cochleae with } \\
\text { incomplete cochlear turns, B. } \\
\text { EVA, L. }\end{array}$ & Global developmental delay \\
\hline
\end{tabular}


Table 1. Cont.

\begin{tabular}{|c|c|c|c|c|c|}
\hline ID & Age at CI (yr) & Sex & Temporal Bone Findings & Clinical History & Gene \\
\hline 5 & 3.84 & $\mathrm{~F}$ & HJB with dehiscence, $\mathrm{L}$ & $\begin{array}{c}\text { Prenatal antibiotic use for } \\
\text { maternal respiratory infection. } \\
\text { Patient used antibiotics in } \\
\text { neonatal period for } \\
\text { unspecified infection. Has } \\
\text { pervasive } \\
\text { developmental delay. }\end{array}$ & DMXL2 \\
\hline 6 & 10.81 & M & PSCD + HJB, B. EVA, R. & $\begin{array}{l}\text { Pneumonia, sinusitis, and } \\
\text { progressive hearing loss }\end{array}$ & PTPRQ \\
\hline 7 & 8.00 & $\mathrm{~F}$ & HJB, L. OM, L. & $\begin{array}{l}\text { Mild motor delay and } \\
\text { hypotonia. History of urinary } \\
\text { and upper respiratory tract } \\
\text { infections. }\end{array}$ & $\begin{array}{c}\text { MYO7A; } \\
\text { PCDH15/CDH23 }\end{array}$ \\
\hline 8 & 3.03 & M & SSCD, L & $\mathrm{U} / \mathrm{R}$ & COL11A1; TECTA \\
\hline 9 & 8.19 & $\mathrm{~F}$ & EVA, L & $\begin{array}{l}\text { Mother had urinary tract } \\
\text { infection and eclampsia } \\
\text { during pregnancy }\end{array}$ & IST1 \\
\hline 13 & 5.95 & M & Normal & Global developmental delay & SLC12A2 \\
\hline 18 & 2.77 & M & Normal & $\begin{array}{c}\text { Sepsis and } \\
\text { antibiotic/amikacin use } \\
\text { during neonatal period }\end{array}$ & MYO7A \\
\hline 19 & 5.66 & $\mathrm{~F}$ & $\begin{array}{l}\text { Malformed cochleae, } \\
\text { vestibules and semi-circular } \\
\text { canals, B. Absent cochlear and } \\
\text { inferior vestibular nerves, R. }\end{array}$ & $\begin{array}{l}\text { Maternal diabetes at } 6 \text { months } \\
\text { gestation }\end{array}$ & MYO18B \\
\hline 20 & 14.59 & $\mathrm{~F}$ & Normal & $\begin{array}{l}\text { Fluctuating hearing loss with } \\
\text { steeply sloping audiogram } \\
\text { prior to CI. Turbinate } \\
\text { hypertrophy, allergic rhinitis, } \\
\text { nasopharyngeal nodule. }\end{array}$ & CLDN9 \\
\hline 22 & 4.40 & $\mathrm{~F}$ & Normal & $\mathrm{U} / \mathrm{R}$ & GREB1L; CBLN3 \\
\hline 23 & 4.61 & $\mathrm{~F}$ & Normal & $\mathrm{U} / \mathrm{R}$ & CDH23; MYO18B \\
\hline 24 & 6.10 & M & EVA, B & $\begin{array}{c}\text { Fever, jaundice, foul umbilical } \\
\text { discharge and apneic episodes } \\
\text { with antibiotics and } \\
\text { phototherapy in neonatal } \\
\text { period }\end{array}$ & FLNA \\
\hline 27 & 7.72 & $\mathrm{~F}$ & EVA, B. OM, L. & $\mathrm{U} / \mathrm{R}$ & GDPD5 \\
\hline
\end{tabular}

M, male; F, female; U/R, unremarkable; B, bilateral; L, left; R, right; EVA, enlarged vestibular aqueduct; HJB, high jugular bulb; OM, otitis media; PSCD, posterior semicircular canal dehiscence; SSCD, superior semicircular canal dehiscence.

\section{Materials and Methods}

Out of our initial cohort of 30 Filipino patients, we previously identified a genetic variant as causal of hearing loss in 15 patients [32-34]. For this study, we reviewed the clinical records and temporal bone images of 15 Filipino cochlear implantees for whom no variants in known hearing loss genes were identified previously (Table 1) [34]. High-resolution computed tomography with 2-3 mm axial cuts and without contrast was performed using a Siemens Somatom Plus 4 CT Scanner in order to document temporal bone anomalies. DNA samples were submitted for exome sequencing at the University of Washington Northwest Genomics Center, as previously described [33,34]. The Roche NimbleGen SeqCap EZ Human Exome Library v.2.0 ( $\sim 37 \mathrm{Mb}$ target) was used for sequence capture, 
and sequencing was performed using an Illumina HiSeq to an average depth of $30 \times$. Fastq files were aligned to the hg19 human reference sequence using Burrows-Wheeler Aligner, generating demultiplexed .bam files [35]. The Genome Analysis Tool Kit was used for realignment of indel regions (IndelRealigner), variant quality score recalibration (VQSR) and variant detection and calling, as well as generation of standard metrics used for quality control (QC) during exome analyses [36]. Low-quality and likely false-positive variants were flagged. The initial .vcf file for 29 GJB2-negative individuals included 82,853 variants, of which 74,965 passed QC filters. Variants from the entire .vcf file were annotated using ANNOVAR (annovar.openbioinformatics.org, last accessed March 18, 2021) [37]. Indels from the exome sequence data were also annotated using MutationTaster [38], however no rare or low-frequency variants were identified as potentially deleterious in the 15 patients studied.

Single nucleotide variants that passed QC were initially selected if they: (a) were homozygous or heterozygous in the 15 children with no known genetic etiology of hearing loss; (b) were stop, splice or missense variants; (c) had a minor allele frequency (MAF) $<0.005$ in any gnomAD (gnomad.broadinstitute.org, last accessed 31 March 2021), 1000 Genomes or Greater Middle East (GME) Variome population [4,39,40]; (d) from the Combined Annotation Dependent Depletion (CADD; cadd.gs.washington.edu, last accessed 31 March 2021) pre-computed scores database, had a scaled CADD score of $\geq 15$ [41]; and (e) was predicted to be deleterious by at least one bioinformatics tool from dbSNFP41a [42]. Variants were excluded if they were common across our cohort, particularly if occurring within genes not previously associated with hearing loss but are found in multiple individuals that were identified to have variants in known genes for hearing loss [32-34]. This selection strategy resulted in a shorter list of 2570 variants, which was parsed further by prioritizing any variant that: (a) lies within a known hearing loss gene; (b) is a loss-of-function variant; (c) lies within a potentially novel gene but is homozygous or with two variants in the same gene in the same individual; and/or (d) lies within a gene that is identified in a mouse model with hearing loss. A list of 120 variants were rechecked against equivalent hg38 databases. Additional MAF checking was performed using the GenomeAsia 100K database (genomeasia100k.org, last accessed March 31, 2021) [43]. For known hearing loss genes, variants were ruled out if they occurred in a gene in which phenotypes are expressed only in homozygous or compound heterozygous individuals and the patient genotype is heterozygous. For the final list of 89 variants (Table S1), the Integrative Genomics Viewer v2.8.3 was used to visualize variants from exome sequence data [44].

\section{Results}

Of the 15 children studied, six had EVA, three with high jugular bulb (HJB), two with SSCD/PSCD and two with malformed cochleae (Figure 1; Table 1). Five children had normal temporal bone CT/MRI images. From clinical history, seven children had exposures to infections and antibiotics, whether prenatally, at the neonatal stage or during early childhood (Table 1), suggesting that the previous infections or antibiotic use may have also played a role in their hearing loss etiology. Prior to CI, hearing loss in the 15 children was congenital, prelingual and severe-to-profound across frequencies, except for: (a) ID6 who had progressive hearing loss; and (b) ID20 who had fluctuating hearing loss with a steeply sloping audiogram and profound hearing loss at the high frequencies (Table 1). 


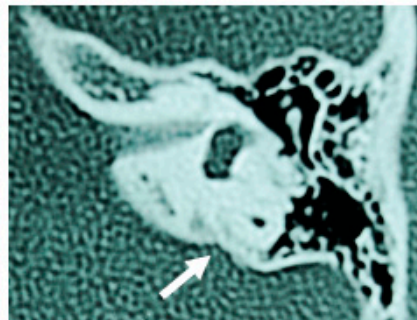

A. ID1, L: EVA

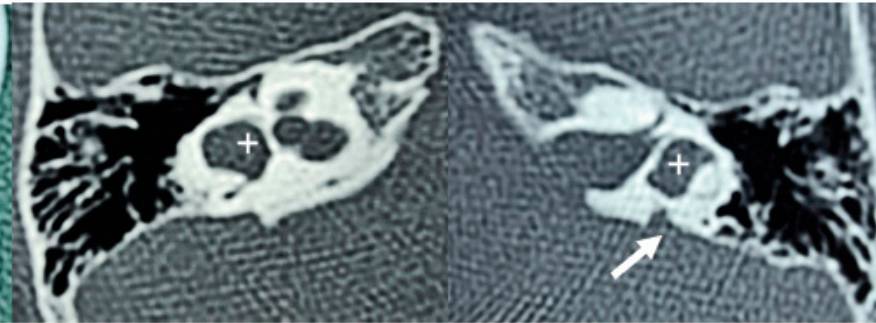

B\&C. ID3: Malformed cochleae, B; EVA, L

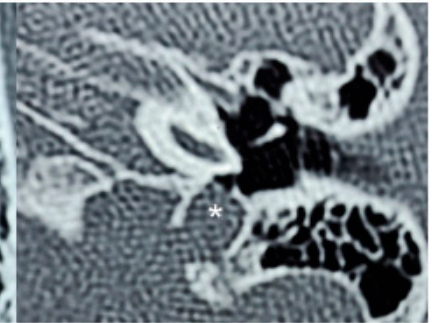

D. ID5, L: HJB

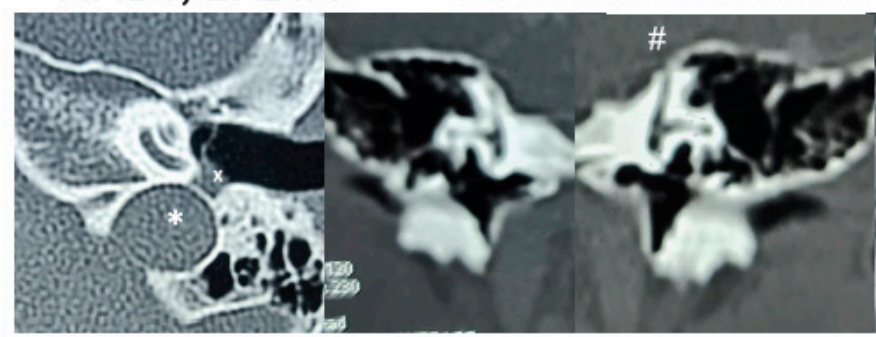

E. ID7, L: HJB
F\&G. ID8, L: SSCD

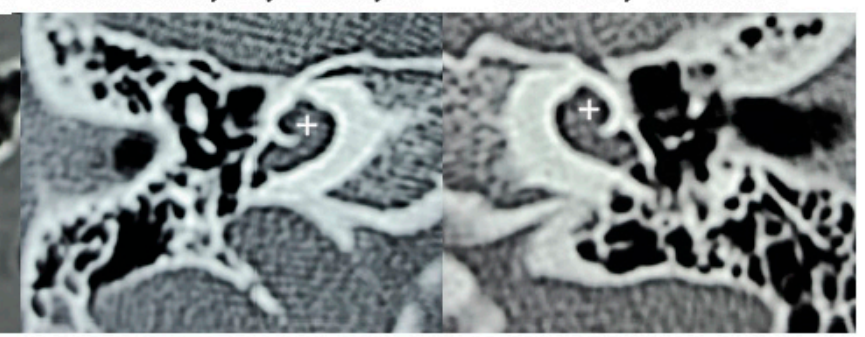

H\&I. ID19, R\&L: Cochleovestibular malformation

Figure 1. Temporal bone images in six patients with hearing loss. (A) ID1 with the heterozygous DSPP c.730G $>A$ (p.(Gly244Arg)) variant has enlarged vestibular aqueduct (EVA, arrow) on the left. (B,C) ID3 with the heterozygous LMX1A and COL2A1 variants has bilaterally malformed cochleae with incomplete cochlear turns (plus signs) and left-sided EVA (arrow). (D) ID5 with the heterozygous DMXL2 variant has a high jugular bulb (HJB, asterisk) on the left. (E) ID7 with the heterozygous MYO7A variant plus potentially compound heterozygous $P C D H 15$ and $C D H 23$ variants has HJB (asterisk) on the left. There is also fluid in the middle ear space (marked by X), indicating otitis media. (F,G) ID8 with the heterozygous COL11A1 and TECTA variants has left-sided superior semicircular canal dehiscence (SSCD, hash sign). (H,I) ID19 with the heterozygous MYO18B c.2555C>T (p.(Ala852)) variant has multiple congenital inner ear anomalies with bilaterally malformed cochleae, vestibules and semicircular canals (plus signs), as well as absence of the right cochlear and inferior vestibular nerves.

A total of 21 rare/low-frequency potentially deleterious variants were identified in 17 genes (Tables 1 and 2), all of which are known to be expressed in the mouse cochlea (gEAR, umgear.org, last accessed March 31, 2021). Although majority of the variants were heterozygous with likely autosomal dominant (AD) inheritance, several variants had seemingly different modes of inheritance, such as: (1) a homozygous CLDN9 variant in ID20; (2) potentially compound heterozygous variants in GDPD5, PCDH15 and/or CDH23 in three children; and (3) an X-linked variant in FLNA in male patient ID24 (Table S1). While our knowledge of mode of inheritance of these variants is limited, for five individuals the available history matches either an autosomal recessive (AR) pattern or AD inheritance with decreased penetrance (Table S1). A more detailed genotype-phenotype correlation per gene and patient is hereby presented. 
Table 2. Novel variants and candidate genes ${ }^{1}$ for hearing loss and temporal bone anomalies.

\begin{tabular}{|c|c|c|c|c|c|c|c|}
\hline ID & Gene & Variant & rsID & gnomAD & $\begin{array}{c}\text { GenomeAsia 100k } \\
\text { SEA }^{2}\end{array}$ & Scaled CADD & $\begin{array}{l}\text { Damaging Results from } \\
\text { dbNSFP Tools }\end{array}$ \\
\hline 1 & $D S P P$ & $\begin{array}{c}\text { NM_014208: c.730G }>A \\
(p .(\text { Gly244Arg) })\end{array}$ & 1044690454 & NA & 0.0014 & 24.3 & FA,mLR,mSVM, MT,PP2,SI \\
\hline 3 & $L M X 1 A$ & $\begin{array}{c}\text { NM_177398: c.606G>C } \\
(\text { p.(Leu202Phe }))\end{array}$ & NA & NA & NA & 24.8 & $\begin{array}{c}\text { FA,LRT,mLR, } \\
\text { mSVM,MT,PP2, PR,SI }\end{array}$ \\
\hline 5 & DMXL2 & $\begin{array}{c}\text { NM_015263: c.257T }>C \\
(\text { p.(Leu86Ser }))\end{array}$ & 761692429 & OTH: 0.0005 & NA & 24.1 & LRT,MT,PP2,SI \\
\hline 6 & $P T P R Q$ & $\begin{array}{c}\text { NM_001145026: c.6179T }>C \\
(p .(\text { Val2060Ala }))\end{array}$ & 375150180 & EAS: 0.00097 & 0.017 & 27.8 & MT,SI \\
\hline 7 & PCDH15/CDH23 & $\begin{array}{l}\text { NM_001354411: c.3787C>T } \\
\text { (p.(Pro1263Ser)); NM_022124: } \\
\text { c.3262G >A (p.(Val1088Met)) }\end{array}$ & $775954124 ; 200632520$ & $\begin{array}{c}\text { EAS: } 0.004 ; \text { EAS: } \\
0.002\end{array}$ & NA; 0.003 & $24.9 ; 24.3$ & $\begin{array}{l}\text { MA,MT,PP2,PR, SI; } \\
\text { LRT,MA,mLR, } \\
\text { mSVM,MT,PP2,SI }\end{array}$ \\
\hline 23 & $\mathrm{CDH} 23$ & $\begin{array}{c}\text { NM_022124: c.437C >T } \\
\text { (p.(Pro146Leu)); c.3262G }>\text { A } \\
\text { (p.(Val1088Met)); c.6911G }>\text { A } \\
\text { (p.(Arg2304Gln)) }\end{array}$ & $\begin{array}{c}765103490 \\
200632520 ; 201434373\end{array}$ & $\begin{array}{l}\text { NA; EAS: } \\
0.002 \text {; EAS: } \\
0.0015\end{array}$ & $0.001 ; 0.003 ; 0.007$ & $24.7 ; 24.3 ; 22.7$ & $\begin{array}{c}\text { LRT,MT,PP2,PR, SI; } \\
\text { LRT,MA,mLR, } \\
\text { mSVM,MT,PP2,SI; MT,SI }\end{array}$ \\
\hline 8 & COL11A1 & $\begin{array}{l}\text { NM_080629: c.4364A>C } \\
\quad(p .(L y s 1455 T h r))\end{array}$ & 769350133 & EAS: 0.0004 & NA & 28.6 & $\begin{array}{c}\text { FA,LRT,mLR, } \\
\text { mSVM,MT,PP2, PR,SI }\end{array}$ \\
\hline 8 & TECTA & $\begin{array}{c}\text { NM_005422: c.2967C }>A \\
(p .(H i s 989 G \ln )\end{array}$ & 200821009 & EAS: 0.003 & 0.0014 & 20.4 & $\begin{array}{c}\text { FA,LRT,mLR, } \\
\text { mSVM,MT,PP2, PR,SI }\end{array}$ \\
\hline 9 & IST1 & $\begin{array}{c}\text { NM_001270976: c.737C }>G \\
\text { (p.(Pro246Arg)) }\end{array}$ & 774343604 & EAS: 0.0002 & NA & 24.0 & LRT,MT,PP2,PR, SI \\
\hline 13 & SLC12A2 & $\begin{array}{c}\text { NM_001046: c.2977G }>T \\
(p .(\text { Glu993*)) }\end{array}$ & NA & NA & NA & 60.0 & MT \\
\hline 19 & MYO18B & $\begin{array}{c}\text { NM_032608: c.2555C }>T \\
(p .(\text { Ala852Val }))\end{array}$ & NA & NA & NA & 26.1 & $\begin{array}{c}\text { FA,LRT,mLR, } \\
\text { mSVM,MA,MT, PP2,PR,SI }\end{array}$ \\
\hline 23 & MYO18B & $\begin{array}{c}\text { NM_032608: c.1982G>A } \\
\left(p .\left(\operatorname{Trp} 661^{*}\right)\right.\end{array}$ & 372939044 & AFR: 0.0005 & NA & 44.0 & $\mathrm{LRT} / \mathrm{MT}$ \\
\hline
\end{tabular}


Table 2. Cont.

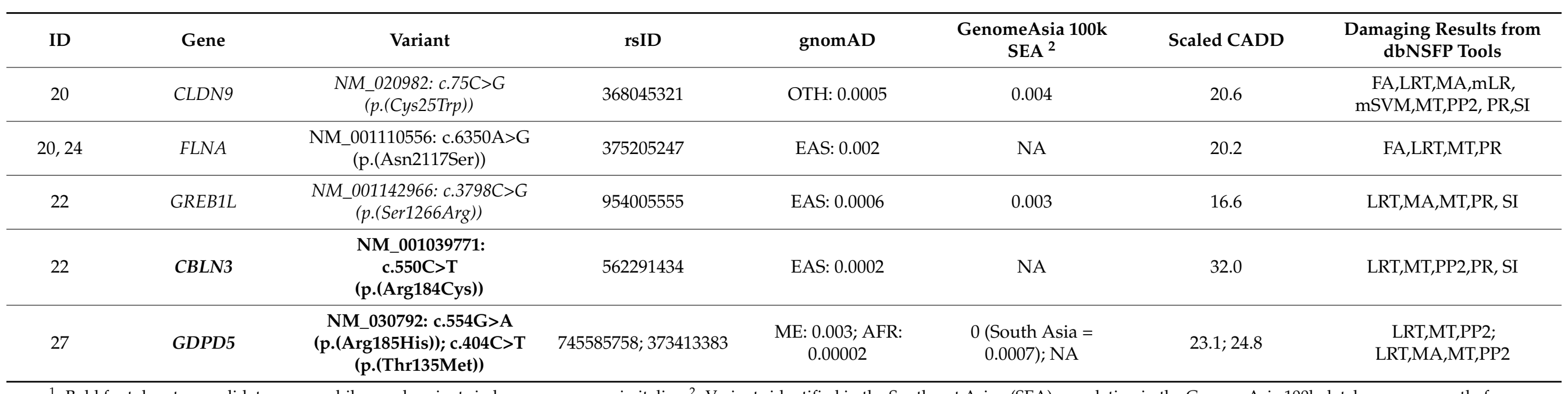

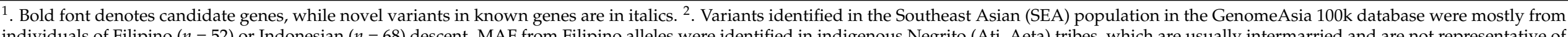

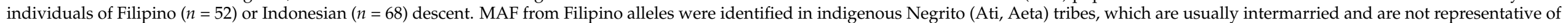

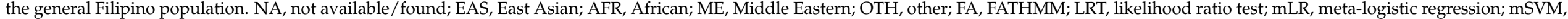
meta-support vector machine; MA, MutationAssessor; MT, MutationTaster; PP2, PolyPhen2; PR, PROVEAN; SI, SIFT. 
DSPP: Variants in DSPP (MIM 125485; 4q22.1) were first identified as a cause of AD hearing loss DFNA39 with dentinogenesis (MIM 605594) in Chinese families with dentinogenesis imperfecta 1 and adult-onset progressive sensorineural high-frequency hearing loss [45]. Additional hearing loss families, all of East Asian ethnicity, have been identified to have splice or missense variants within the first five exons of DSPP [46-48]. In the reported families, there was variability in age of onset, affected hearing frequencies, severity of hearing loss, and symptoms of tinnitus or balance problems [45-48]. In one family, the affected individuals had congenital hearing loss and bilateral cochlear defects with or without EVA [47]. In our study, patient ID1 had congenital hearing loss and unilateral EVA (Table 1; Figure 1). He was heterozygous for a novel variant c.730G $>$ A (p.(Gly244Arg)), which lies within exon 4 of DSPP (Table 2). Although we have no record of dental abnormalities, he had small cysts identified in his brain MRI (Table 1). Dspp is expressed in inner ear, brain and pericytes of blood vessels in dental pulp of mice, and also in zebrafish otoliths $[45,49,50]$. He also has additional variants in ANLN (MIM 616027; 7p14.2), ZNF462 (MIM 617371; 9q31.2), and CEP290 (MIM 610142; 12q21.32). Each of these three genes harbor variants previously associated with hearing loss in various syndromes (Table S1): branchio-otic syndrome with ossicular chain anomalies for ANLN [6]; Weiss-Kruszka syndrome with craniofacial dysmorphisms and developmental delay for ZNF462 [51]; and Joubert syndrome with cerebral, retinal and kidney disease for CEP290 [52]. While we cannot rule out if ID4's brain cysts are related to these syndromic genes (e.g., kidney cysts are common in individuals with CEP290 variants) [52], the other features of these syndromes are absent in patient ID1. Overall, the DSPP variant in ID6 fits his inner ear findings.

LMX1A: In addition to hearing loss, ID3 has malformed cochleae, left-sided EVA and global developmental delay (Figure 1; Table 1). Both the hearing loss and bony cochlear defects may be explained by novel heterozygous variants in two genes, namely $L M X 1 A$ (MIM 600298; 1q23.3) c.606G>C (p.(Leu202Phe)) and/or COL2A1 (MIM 120140; 12q13.11) c.3569G >A (p.(Arg1190His)) (Table 2 and Table S1). LMX1A is known for AD or AR nonsyndromic hearing loss $[53,54]$, while COL2A1 is related to Stickler syndrome type 1 with hearing loss (MIM 108300) as well as various skeletal phenotypes [55]. Homozygous Lmx1a-mutant mice lack endolymphatic ducts and have short cochlear ducts [56], which seem to recapitulate the incomplete cochlear turns and EVA in patient ID2. Additionally, hair cell loss and disorganization were seen in the cochleae of mutant mice [57]. However, unlike the deaf homozygous mice, the $\operatorname{Lix} 1 a$-heterozygous mice had normal hearing [56]. In contrast, two Dutch families with heterozygous missense $L M X 1 A$ variants had mildto-profound hearing loss of variable onset from infancy to adulthood [53]. On the other hand, a transgenic Col2a1-mutant mouse model had a smaller misshapen otic capsule as well as craniofacial abnormalities such as cleft palate and short mandible [58]; these latter features were not found in our patient ID3. In patient ID3, two variants in USH2A (MIM 608400; 1q41) were previously ruled out due to high MAF in the general Filipino population and lack of retinitis pigmentosa after years of follow-up (Table S1). There were three other interesting variants in ID3 (Table S1): (a) heterozygous missense variant in ZFHX4 (MIM 606940; 8q21.13)-ZFHX4 is one of two genes within the minimum region of overlap in patients with 8 q21 microdeletions manifesting with intellectual and developmental disability, sensorineural hearing loss, craniofacial anomalies and hypotonia $[59,60]$; (b) heterozygous missense variant in NRP1-the $N r p 1^{+/-}$mouse has abnormal auditory brainstem responses (ABR), progressive hearing loss, disorganized outer spiral bundles and enlarged microvessels of the stria vascularis [61]; and (c) a hemizygous missense variant in ARHGAP4 (MIM 300023; Xq28), in which missense variants were previously described in children with intellectual disability $[62,63]$. This case shows potential overlap of clinical presentation due to multiple deleterious variants, of which the $L M X 1 A$ variant is the strongest etiology of inner ear abnormalities in this patient while the ZFHX4 or ARHGAP4 variants may explain ID3's developmental delay. 
DMXL2: DMXL2 (MIM 612186; 15q21.2) was recently identified to have missense variants causing $\mathrm{AD}$ nonsyndromic hearing loss in Chinese and Cameroonian families [64,65]. In these families, the affected individuals were mostly adult with progressive hearing loss and no reported temporal bone abnormalities, although one Cameroonian child had congenital profound hearing loss [65]. Our patient ID5 has a novel heterozygous DMXL2 variant c.257T >C (p.(Leu86Ser)) (Table 2). In addition to prelingual profound hearing loss, her temporal bone CT showed a left HJB with evidence of dehiscence (Figure 1). She also had a history of neonatal infection as well as pervasive developmental delay (Table 1). In mice, cochlear expression of Dmxl2 is limited to the hair cells and spiral ganglion neurons [64], and Dmxl2-knockout leads to preweaning lethality in the homozygous mouse and decreased bone mineral content if heterozygous (International Mouse Phenotyping Consortium (IMPC), www.mousephenotype.org, last accessed March 31, 2021). It is possible that the temporal bone findings are also an effect of the Dmxl2 variant in ID5's case. Biallelic loss-of-function DMXL2 variants are also known to cause Ohtahara syndrome characterized by neurologic deficits including intellectual disability, developmental delay, hearing loss, polyneuropathy and also facial dysmorphisms [66]. However because patient ID5 only has a heterozygous DMXL2 variant, the developmental delay may also be due to other causes, such as variants in CCDC186 (MIM 619249; 10q25.3), ZRF2 or MCM3AP (MIM 603294; 21q22.3) (Table S1).

PTPRQ: PTPRQ (MIM 603317; 12q21.3) is a known cause of AD (MIM 617663) or AR (MIM 613391) nonsyndromic hearing loss in families and probands with multiple ethnicities, which may be variable in clinical presentation [67,68]. Patient ID6 is heterozygous for a novel missense variant c.6179T $>\mathrm{C}$ (p.(Val2060Ala)) within PTPRQ (Table 2). He also has progressive hearing loss, bilateral PSCD and HJB and right-sided EVA as temporal bone findings, as well as previous pneumonia and sinusitis (Table 1). In general previous reports of $P T P R Q$-related hearing loss excluded temporal bone anomalies, however narrowed internal auditory canals were found in a Chinese proband with compound heterozygous $P T P R Q$ variants [69]. We previously ruled out a heterozygous variant in TCOF1 (MIM 606847; 5q32-q33) due to lack of clinically diagnosed craniofacial hallmarks of AD Treacher-Collins syndrome (MIM 154500), but upon review, we cannot rule out that the TCOF1 variant also contributes to hearing loss and temporal bone anomalies, as was previously described (Table S1) [70]. Lastly a heterozygous variant in DNAH14 (MIM 603341; 1q42.12), a candidate gene for primary ciliary dyskinesia and lung function in cystic fibrosis (Table S1) [71,72], may play a role in ID6's susceptibility to airway infections.

$P C D H 15, C D H 23$ and MYO7A: While these three genes are known for Usher syndrome, they have AR nonsyndromic forms of hearing loss. In addition, MYO7A (MIM 276903; 11q13.5) variants may be inherited in an AD manner, while digenic inheritance for PCDH15 (MIM 605514; 10q21.1) and CDH23 (MIM 605516; 10q22.1) were demonstrated in mice and humans [73]. ID7 has hearing loss, HJB, mild motor delay, hypotonia, and urinary and upper respiratory infections (Figure 1; Table S1). She has multiple variants of interest, but the strongest findings are compound heterozygous $P C D H 15 / C D H 23$ variants plus a heterozygous MYO7A variant (Table 2). Interestingly, the same $M Y O 7 A$ variant c.4921G $>A$ (p.(Glu1461Lys)) is heterozygous in another patient ID18, who has nonsyndromic hearing loss (Table 2). This may suggest that the additional variants in ID7 contribute to her variable phenotype (Table S1). Patient ID23 also has nonsyndromic hearing loss and three $C D H 23$ variants, however we could not confirm if these $C D H 23$ variants are compound heterozygous or inherited in cis due lack of available parental DNA (Table 2). These CDH23 and MYO7A variants are reported as variants of unknown significance (VUS) in ClinVar (www.ncbi.nlm.nih.gov/ clinvar/, last accessed 31 March 2021), while the PCDH15 c.3787C $>$ T (p.(Pro1263Ser)) variant is novel.

COL11A1: ID8 has hearing loss, left-sided SSCD, and heterozygous missense variants in two genes known for AD nonsyndromic hearing loss, namely COL11A1 (MIM 120280; 1p21.1) and TECTA (MIM 602574; 11q23.3) (Tables 1 and 2; Figure 1). Of the two deleterious variants, the COL11A1 c.4364A $>C$ (p.(Lys1455Thr)) variant is rarer (gnomAD EAS MAF $=0.0004)$. Pre- 
vious reports on COL11A1 or TECTA did not reveal inner ear abnormalities in patients with variants [74,75].

IST1: ID9 with profound hearing loss and left-sided EVA is heterozygous for a c.737C >G (p.(Pro246Arg)) variant in IST1 (MIM 616434; 16q22.2). This rare deleterious variant (Table 2) was singled out due to a heterozygous Ist1 mouse model that had abnormal ABR in early adulthood (IMPC). In mouse cochlea, Ist 1 is expressed in both hair cells and supporting cells (gEAR). Recently de novo VPS4A variants were identified to cause a multi-systemic neurodevelopmental disorder including sensorineural hearing loss due to the abnormal accumulation of IST1 protein in the limiting membrane of proband-derived fibroblasts and also in neuronal endosomes [76], suggesting that proper localization of IST1 is required for neuronal function. Taken together, our findings make IST1 an excellent candidate gene for nonsyndromic hearing loss. Moreover, ID9 had poor CI outcomes, such as average $\mathrm{CI}$-aided hearing threshold of $74 \mathrm{~dB}$ and speech tests using PEACH scores at $10-21 \%$. Identification of additional patients with IST1 variants is needed to verify these CI outcomes.

SLC12A2: ID13 who has hearing loss and global developmental delay is heterozygous for a novel stop variant c.2977G > T (p.(Glu993*)) in SLC12A2 (also NKCC1; MIM 600840; 5q23.3) (Tables 1 and 2). SLC12A2 variants have been identified in patients with $A D$ nonsyndromic hearing loss (MIM 619081), with AD Delpire-McNeill syndrome (MIM 619083), or AR Kilquist syndrome (MIM 619080). Recently McNeill et al. identified heterozygous SLC12A2 variants in eight mostly pediatric patients with intellectual disability or developmental delay, and $\sim 60 \%$ had bilateral sensorineural hearing loss [18]. Previous homozygous knockout of Slc12a2 in mice led to loss of hearing and vestibular function, collapse of Reissner's membrane, disorganization of the organ of Corti, and loss of hair cells and supporting cells [77]. On the other hand, heterozygous deletion of Slc12a2 in mice resulted in early hearing loss that progressed with age despite normal inner ear morphology and histology [78].

MYO18B: Two patients had variants in MYO18B (MIM 607295, 22q12.1). Patient ID23 with nonsyndromic hearing loss has potentially compound heterozygous $\mathrm{CDH} 23$ variants and also a novel heterozygous MYO18B variant c.1982G>A (p.(Trp661*)) (Table 2). The other patient ID19 has another novel variant c.2555C $>\mathrm{T}$ (p.(Ala852Val)) and severe cochleovestibular defects (Figure 1). In patient ID19, no other strong candidate variants or genes were identified (Table S1). MYO18B variants were previously associated with autosomal recessive Klippel-Feil syndrome (MIM 616549) which is characterized by nemaline myopathy, facial dysmorphisms and hearing loss in up to $60 \%$ of patients [79]. Heterozygous Myo18b-knockout mice had abnormal ABR findings (IMPC), further supporting the role of heterozygous $M Y O 18 B$ variants in the etiology of hearing loss. Patients with hearing loss as part of Klippel-Feil syndrome were also diagnosed with inner ear dysplasias including internal acoustic canal deformities [80], which are similar to the temporal bone anomalies found in patient ID19 (Figure 1). Of the 30 Filipino patients, ID19 and ID23 who carry MYO18B variants had poorer outcomes after CI, with PEACH scores whether in quiet or noise at $4-37 \%$ despite average post-CI thresholds of $\sim 40 \mathrm{~dB}$ at $0.25-8 \mathrm{kHz}$. This is not unexpected given potential cochlear nerve defects [30,31] that might not have been diagnosed radiologically (Figure 1). For ID19, her PEACH scores improved to $>80 \%$ after 5 years of continued use of her implant on the left ear.

FLNA: The same FLNA (MIM 300017; Xq28) variant c.6350A >G (p.(Asn2117Ser)) that is classified as VUS in ClinVar was identified in two children ID20 and ID24 (Table 2). ID24 is male, hemizygous for the $F L N A$ variant and has no other rare damaging variants in hearing loss genes. He is hemizygous for a known pathogenic variant in G6PD (MIM 305900; Xq28) which may explain his neonatal jaundice (Table 1 and Table S1). FLNA is associated with multiple disorders, of which frontometaphyseal dysplasia (MIM 305620), Melnick-Needles syndrome (MIM 309350) and otopalatodigital syndrome (MIM 311300/304120) have been reported to include sensorineural hearing loss. ID24 has EVA in addition to the hearing loss but has no detailed assessment of additional skeletal anomalies; meanwhile temporal bone 
anomalies have been reported previously in a patient with Melnick-Needles syndrome [81]. On the other hand, the female patient ID20 who is heterozygous for the same FLNA variant has additional variants as the cause of hearing loss (Table S1).

CLDN9: ID20 has fluctuating hearing loss at the high frequencies and additional sinonasal findings (Table 1). In addition to the FLNA variant, she is homozygous for a novel variant c.75C>G (p.(Cys25Trp)) in CLDN9 (MIM 615799; 16p13.3) and heterozygous for ANKRD11 (MIM 611192; 16q24.3) (Table 2 and Table S1). KBG syndrome (MIM 148050) due to heterozygous $A N K R D 11$ variants manifests variably as macrodontia, intellectual disability and skeletal/craniofacial defects, including conductive or mixed hearing lossthese features do not fit the patient's clinical presentation [82]. In contrast, a CLDN9 frameshift variant was found in a Turkish family with AR nonsyndromic, progressive highfrequency hearing loss [83]; this clinical description is similar to that of ID20. In Cldn9-/ mice, defective tight junctions in the cochlea are hypothesized to cause the increased concentration $\mathrm{K}^{+}$in the perilymph and massive hair cell loss [84]. In this case the sinonasal findings are probably not related to genetic susceptibility.

GREB1L: Previously variants in GREB1L (MIM 617782; 18q11.1-q11.2) were associated with AD nonsyndromic hearing loss with or without cochleovestibular malformations and non-ear phenotypes [20-22]. Our patient ID22 is heterozygous for a novel missense variant GREB1L c.3798C>G (p.(Ser1266Arg)) but has no other features in addition to profound hearing loss (Table 1, Table 2 and Table S1). She also has a heterozygous variant in CBLN3 (MIM 612978; 14q12). Cbln3 is expressed in supporting cells and outer hair cells of the inner ear (gEAR), and also in the cerebellum and dorsal cochlear nucleus [85]. Heterozygous Cbln3-mutant mice have abnormal ABR (IMPC), implying that CBLN3 is also a candidate gene for ID22's hearing loss.

GDPD5: Patient 27 has two missense variants each in two genes: GDPD5 (also GDE2, MIM 609632; 11q13.4-q13.5) which encodes an enzyme involved in glycerol metabolism; and MADD (MIM 603584; 11p11.2) (Table S1). Gdpd5 is expressed in hair cells and supporting cells of mouse cochlea (gEAR) and homozygous knockout mice have abnormal ABRs (IMPC). On the other hand, biallelic MADD variants cause a multisystemic neurodevelopmental disorder that includes sensorineural hearing loss in 17\% of patients [86]. Our patient ID27 has hearing loss and bilateral EVA with no note of additional neurologic phenotypes (Table 1), suggesting that GDPD5 is a candidate gene for her hearing loss.

\section{Discussion}

In this study, we identified novel variants in 14 genes: twelve are novel variants in eleven known hearing loss or neurodevelopmental genes DSPP, LMX1A, DMXL2, PTPRQ, PCDH15, COL11A1, TECTA, SLC12A2, MYO18B, CLDN9 and GREB1L; while four variants are in candidate genes for hearing loss IST1, CBLN3 and GDPD5 (Table 2). In addition, several inner ear and temporal bone malformations were identified in variant carriers, namely: (1) EVA in carriers of DSPP, IST1, FLNA and GDPD5 variants; (2) semicircular canal dehiscence in carriers of DMXL2, PTPRQ and COL11A1/TECTA variants; and (3) malformed cochleae in carriers of variants in $L M X 1 A$ and $M Y O 18 B$ (Table 1; Figure 1). These findings suggest that at least some of these variants (e.g., variants in DSPP, LMX1A and MYO18B) are also potentially causal of temporal bone anomalies. Factors that may have contributed to an increased rate of variant identification from the sequence data of our cohort of 30 pediatric cochlear implant recipients include: (a) a more inclusive approach for lowfrequency variants, particularly if the MAF was increased in an indigenous or isolated population which has high rates of intermarriage and potentially undiagnosed hearing loss (Table 2) $[43,87,88]$; and (b) genotype-phenotype correlation that takes into account additional clinical manifestations (e.g., developmental delay, recurrent infections) which overlap with features of syndromes or multi-systemic neurodevelopmental disorders. In the latter case, hearing loss might not be among the major criteria of the disorder, but the overall clinical presentation of the specific patient may fit previous descriptions of genotype-phenotype correlations that include hearing loss or bony defects. 
Apparent contradictions in modes of inheritance may be due to undetected second variants for autosomal recessive disorders, which is a limitation of our study due to the lack of data on CNVs, cryptic splice sites, and non-coding regions [89]. Unfortunately, we only have DNA samples from patients and not from parents or additional relatives, so we cannot determine the identified variants' pattern of inheritance or if they potentially arose de novo.

It is not unusual for the same gene to cause both autosomal dominant and autosomal recessive forms of hearing loss, e.g., MYO7A (MIM 276903) variants have been associated with either autosomal dominant (MIM 601317) or autosomal recessive non-syndromic hearing loss (MIM 600060), as well as autosomal recessive Usher syndrome type 1B (MIM 276900). Differences in modes of inheritance may be associated with phenotypic variability, such that variants known to cause autosomal recessive hearing loss that is characterized by prelingual profound hearing loss co-exist with heterozygous variants that cause autosomal dominant forms with milder hearing loss of later onset. Additionally, with the increasing number of identified genes for hearing loss, the occurrence of multiple variants within different genes that independently predispose to hearing loss in the same individual may be more common than previously thought [90]. Multiple variants in different genes may also contribute to variability in phenotypes (e.g., two genes with variants in the same individual causing different phenotypes rather than the same syndrome). An example would be ID24 in our cohort, in which a known pathogenic G6PD variant likely explains the patient's neonatal jaundice, while the hearing loss is potentially due to a known variant in FLNA. Continued efforts in identifying novel genes mean that patient sequence data must be periodically reanalyzed not only to resolve a potential genetic etiology, but also to identify compound phenotypes due to variants in multiple genes. If multiple genes or variants are involved, additional studies on the functional effects per variant will aid in the determination of which variant is more strongly contributing to the hearing loss phenotype.

\section{Conclusions}

We identified novel variants in 11 known genes for hearing loss and neurodevelopmental phenotypes. We also present three genes IST1, CBLN3 and GDPD5 as potential candidate genes for hearing loss, all three of which have mouse models with abnormal ABR findings that are matched to the patient's genotype. Our findings highlight the importance of identifying novel variants and genes in well-characterized patients from ethnic groups that are understudied for hearing loss.

Supplementary Materials: The following are available online at https:/ /www.mdpi.com/article/10 .3390 /genes12040566/s1, Table S1: Rare damaging variants identified in 15 Filipino children with hearing loss requiring cochlear implants.

Author Contributions: Conceptualization, R.L.P.S.-C. and C.M.C.; Funding Acquisition, R.L.P.S.-C. and C.M.C.; Data Curation, R.L.P.S.-C., T.K.L.Y., C.A.M.T.-G. and C.M.C.; Formal Analysis, R.L.P.S.-C.; Investigation, R.L.P.S.-C., T.K.L.Y., T.C.B., M.L.C.T., M.E.C.P., C.A.M.T.-G., M.R.T.R.-Q., E.M.C.-d.I.P. and C.M.C.; Project Administration, R.L.P.S.-C., T.K.L.Y., C.A.M.T.-G., M.R.T.R.-Q., E.M.C.-d.l.P. and C.M.C.; Resources, R.L.P.S.-C., K.L.M., N.R.L., C.A.M.T.-G., E.M.C.-d.l.P. and C.M.C.; Supervision, R.L.P.S.-C. and C.M.C.; Validation, T.C.B.; Visualization, R.L.P.S.-C., T.C.B. and C.M.C.; WritingOriginal Draft Preparation, R.L.P.S.-C., T.K.L.Y. and C.M.C.; Writing-Review \& Editing, R.L.P.S.-C., T.K.L.Y., T.C.B., M.L.C.T., K.L.M., T.L.G.C., M.E.C.P., A.L.C., N.R.L., C.A.M.T.-G., M.R.T.R.-Q., E.M.C.d.l.P., C.M.C. All authors have read and agreed to the published version of the manuscript.

Funding: This work was funded by grants PCHRD-DOST FP150010 and UP Manila-NIH 2008-005 (to C.M.C.).

Institutional Review Board Statement: The study was approved by the UP Manila Research Ethics Board (approval no. 2013-401-01). All parents of children who were included in the study provided informed consent.

Informed Consent Statement: All parents of children who were included in the study provided informed consent. 
Acknowledgments: We thank the patients and their parents for their participation in this study. We also thank C. Garcia and M. Pedro for administrative support.

Conflicts of Interest: C.T. is an employee of MED-EL, but MED-EL had no role in the study design, data analysis and manuscript preparation. All authors declare no conflict of interest.

\section{References}

1. GBD 2017 Disease and Injury Incidence and Prevalence Collaborators. Global, regional, and national incidence, prevalence, and years lived with disability for 354 diseases and injuries for 195 countries and territories, 1990-2017: A systematic analysis for the Global Burden of Disease Study 2017. Lancet 2018, 392, 1789-1858. [CrossRef]

2. Dai, P.; Huang, L.H.; Wang, G.J.; Gao, X.; Qu, C.Y.; Chen, X.W.; Ma, F.R.; Zhang, J.; Xing, W.L.; Xi, S.Y.; et al. Concurrent hearing and genetic screening of 180,469 neonates with follow-up in Beijing, China. Am. J. Hum. Genet. 2019, 105, 803-812. [CrossRef]

3. Omichi, R.; Shibata, S.B.; Morton, C.C.; Smith, R.J.H. Gene therapy for hearing loss. Hum. Mol. Genet. 2019, 29, R65-R79. [CrossRef] [PubMed]

4. Azaiez, H.; Booth, K.T.; Ephraim, S.S.; Crone, B.; Black-Ziegelbein, E.A.; Marini, R.J.; Shearer, A.E.; Sloan-Heggen, C.M.; Kolbe, D.; Casavant, T.; et al. Genomic landscape and mutational signatures of deafness-associated genes. Am. J. Hum. Genet. 2018, 103, 484-497. [CrossRef]

5. Girotto, G.; Morgan, A.; Krishnamoorthy, N.; Cocca, M.; Brumat, M.; Bassani, S.; La Bianca, M.; Di Stazio, M.; Gasparini, P. Next generation sequencing and animal models reveal SLC9A3R1 as a new gene involved in human age-related hearing loss. Front. Genet. 2020, 10, 142. [CrossRef] [PubMed]

6. Deng, L.; Liu, Y.; Xia, W.; Hu, J.; Ma, Z. Identification of ANLN as a new likely pathogenic gene of branchio-otic syndrome in a three-generation Chinese family. Mol. Genet. Genomic Med. 2019, 7, e00525. [CrossRef] [PubMed]

7. Bademci, G.; Abad, C.; Incesulu, A.; Elian, F.; Reyahi, A.; Diaz-Horta, O.; Cengiz, F.B.; Sineni, C.J.; Seyhan, S.; Atli, E.I.; et al. FOXF2 is required for cochlear development in humans and mice. Hum. Mol. Genet. 2019, 28, 1286-1297. [CrossRef]

8. Xia, W.; Hu, J.; Ma, J.; Huang, J.; Jing, T.; Deng, L.; Zhang, J.; Jiang, N.; Ma, D.; Ma, Z. Mutations in TOP2B cause autosomaldominant hereditary hearing loss via inhibition of the PI3K-Akt signalling pathway. FEBS Lett. 2019, 593, 2008-2018. [CrossRef]

9. Peter, V.G.; Quinodoz, M.; Pinto-Basto, J.; Sousa, S.B.; Di Gioia, S.A.; Soares, G.; Ferraz Leal, G.; Silva, E.D.; Pescini Gobert, R.; Miyake, N.; et al. The Liberfarb syndrome, a multisystemic disorder affecting eye, ear, bone, and brain development, is caused by a founder pathogenic variant in the PISD gene. Genet. Med. 2019, 21, 2734-2743. [CrossRef]

10. Schrauwen, I.; Melegh, B.I.; Chakchouk, I.; Acharya, A.; Nasir, A.; Poston, A.; Cornejo-Sanchez, D.M.; Szabo, Z.; Karosi, T.; Bene, J.; et al. Hearing impairment locus heterogeneity and identification of PLS1 as a new autosomal dominant gene in Hungarian Roma. Eur. J. Hum. Genet. 2019, 27, 869-878. [CrossRef] [PubMed]

11. Morgan, A.; Koboldt, D.C.; Barrie, E.S.; Crist, E.R.; Garcia, G.G.; Mezzavilla, M.; Faletra, F.; Mosher, T.M.; Wilson, R.K.; Blanchet, C.; et al. Mutations in PLS1, encoding fimbrin, cause autosomal dominant nonsyndromic hearing loss. Hum. Mutat. 2019, 40, 2286-2295. [CrossRef]

12. Dunbar, L.A.; Patni, P.; Aguilar, C.; Mburu, P.; Corns, L.; Wells, H.R.; Delmaghani, S.; Parker, A.; Johnson, S.; Williams, D.; et al Clarin-2 is essential for hearing by maintaining stereocilia integrity and function. EMBO Mol. Med. 2019, 11, e10288. [CrossRef]

13. Boyden, L.M.; Atzmony, L.; Hamilton, C.; Zhou, J.; Lim, Y.H.; Hu, R.; Pappas, J.; Rabin, R.; Ekstien, J.; Hirsch, Y.; et al. Recessive mutations in AP1B1 cause ichthyosis, deafness, and photophobia. Am. J. Hum. Genet. 2019, 105, 1023-1029. [CrossRef] [PubMed]

14. Lu, X.; Zhang, Y.; Chen, L.; Wang, Q.; Zeng, Z.; Dong, C.; Qi, Y.; Liu, Y. Whole exome sequencing identifies SCD5 as a novel causative gene for autosomal dominant nonsyndromic deafness. Eur. J. Med. Genet. 2020, 63, 103855. [CrossRef]

15. Tucker, E.J.; Rius, R.; Jaillard, S.; Bell, K.; Lamont, P.J.; Travessa, A.; Dupont, J.; Sampaio, L.; Dulon, J.; Vuillaumier-Barrot, S.; et al. Genomic sequencing highlights the diverse molecular causes of Perrault syndrome: A peroxisomal disorder (PEX6), metabolic disorders (CLPP, GGPS1), and mtDNA maintenance/translation disorders (LARS2, TFAM). Hum. Genet. 2020, 139, 1325-1343. [CrossRef]

16. Reghan Foley, A.; Zou, Y.; Dunford, J.E.; Rooney, J.; Chandra, G.; Xiong, H.; Straub, V.; Voit, T.; Romero, N.; Donkervoort, S.; et al. GGPS1 mutations cause muscular dystrophy/hearing loss/ovarian insufficiency syndrome. Ann. Neurol. 2020, 88, 332-347. [CrossRef]

17. Mutai, H.; Wasano, K.; Momozawa, Y.; Kamatani, Y.; Miya, F.; Masuda, S.; Morimoto, N.; Nara, K.; Takahashi, S.; Tsunoda, T.; et al. Variants encoding a restricted carboxy-terminal domain of SLC12A2 cause hereditary hearing loss in humans. PLoS Genet 2020, 16, e1008643. [CrossRef] [PubMed]

18. McNeill, A.; Iovino, E.; Mansard, L.; Vache, C.; Baux, D.; Bedoukian, E.; Cox, H.; Dean, J.; Goudie, D.; Kumar, A.; et al. SLC12A2 variants cause a neurodevelopmental disorder or cochleovestibular defect. Brain 2020, 143, 2380-2387. [CrossRef] [PubMed]

19. Zhang, L.; Gao, Y.; Zhang, R.; Sun, F.; Cheng, C.; Qian, F.; Duan, X.; Wei, G.; Sun, C.; Pang, X.; et al. THOC1 deficiency leads to late-onset nonsyndromic hearing loss through p53-mediated hair cell apoptosis. PLoS Genet. 2020, 16, e1008953. [CrossRef] [PubMed]

20. Schrauwen, I.; Kari, E.; Mattox, J.; Llaci, L.; Smeeton, J.; Naymik, M.; Raible, D.W.; Knowles, J.A.; Gage Crump, J.; Huentelman, M.J.; et al. De novo variants in GREB1L are associated with inner ear malformations and deafness. Hum. Genet. 2018, 137, 459-470. [CrossRef] 
21. Kari, E.; Llaci, L.; Go, J.L.; Naymik, M.; Knowles, J.A.; Leal, S.M.; Rangasamy, S.; Huentelman, M.J.; Liang, W.; Friedman, R.A.; et al. Genes implicated in rare congenital inner ear and cochleovestibular nerve malformations. Ear Hear. 2020, 41, 983-989. [CrossRef]

22. Schrauwen, I.; Liaqat, K.; Schatteman, I.; Bharadwaj, T.; Nasir, A.; Acharya, A.; Ahmad, W.; Van Camp, G.; Leal, S.M. Autosomal dominantly inherited GREB1L variants in individuals with profound sensorineural hearing impairment. Genes 2020, $11,687$. [CrossRef]

23. Campbell, C.; Cucci, R.A.; Prasad, S.; Green, G.E.; Edeal, J.B.; Galer, C.E.; Karniski, L.P.; Sheffield, V.C.; Smith, R.J. Pendred syndrome, DFNB4, and PDS/SLC26A4 identification of eight novel mutations and possible genotype-phenotype correlations. Hum. Mutat. 2001, 17, 403-411. [CrossRef]

24. Noonan, K.Y.; Russo, J.; Shen, J.; Rehm, H.; Halbach, S.; Hopp, E.; Noon, S.; Hoover, J.; Eskey, C.; Saunders, J.E. CDH23 related hearing loss: A new genetic risk factor for semicircular canal dehiscence? Otol. Neurotol. 2016, 37, 1583-1588. [CrossRef] [PubMed]

25. Kenna, M.A.; Rehm, H.L.; Frangulov, A.; Feldman, H.A.; Robson, C.D. Temporal bone abnormalities in children with GJB2 mutations. Laryngoscope 2011, 121, 630-635. [CrossRef] [PubMed]

26. De Kok, Y.J.; van der Maarel, S.M.; Bitner-Glindzicz, M.; Huber, I.; Monaco, A.P.; Malcolm, S.; Pembrey, M.E.; Ropers, H.H.; Cremers, F.P. Association between X-linked mixed deafness and mutations in the POU domain gene POU3F4. Science 1995, 267, 685-688. [CrossRef] [PubMed]

27. Elmaleh-Berges, M.; Baumann, C.; Noel-Petroff, N.; Sekkal, A.; Couloigner, V.; Devriendt, K.; Wilson, M.; Marlin, S.; Sebag, G.; Pingault, V. Spectrum of temporal bone abnormalities in patients with Waardenburg syndrome and SOX10 mutations. AJNR Am. J. Neuroradiol. 2013, 34, 1257-1263. [CrossRef] [PubMed]

28. Kari, E.; Llaci, L.; Go, J.L.; Naymik, M.; Knowles, J.A.; Leal, S.M.; Rangasamy, S.; Huentelman, M.J.; Friedman, R.A.; Schrauwen, I. A de novo SIX1 variant in a patient with a rare nonsyndromic cochleovestibular nerve abnormality, cochlear hypoplasia, and bilateral sensorineural hearing loss. Mol. Genet. Genomic Med. 2019, 7, e995. [CrossRef] [PubMed]

29. Vesseur, A.C.; Verbist, B.M.; Westerlaan, H.E.; Kloostra, F.J.J.; Admiraal, R.J.C.; van Ravenswaaij-Arts, C.M.A.; Free, R.H.; Mylanus, E.A.M. CT findings of the temporal bone in CHARGE syndrome: Aspects of importance in cochlear implant surgery. Eur. Arch. Otorhinolaryngol. 2016, 273, 4225-4240. [CrossRef] [PubMed]

30. Papsin, B.C. Cochlear implantation in children with anomalous cochleovestibular anatomy. Laryngoscope 2005, 115, 1-26. [CrossRef]

31. Yoon, P.J.; Sumalde, A.A.M.; Ray, D.C.; Newton, S.; Cass, S.P.; Chan, K.H.; Santos-Cortez, R.L.P. Novel variants in hearing loss genes and associations with audiometric thresholds in a multi-ethnic cohort of US patients with cochlear implants. Otol. Neurotol. 2020, 41, 978-985. [CrossRef]

32. Chiong, C.M.; Cutiongco-de la Paz, E.M.; Reyes-Quintos, M.R.T.; Tobias, C.A.M.; Hernandez, K.; Santos-Cortez, R.L.P. GJB2 variants and auditory outcomes among Filipino cochlear implantees. Audiol. Neurotol. Extra 2013, 3, 1-8. [CrossRef]

33. Chiong, C.M.; Reyes-Quintos, M.R.T.; Yarza, T.K.L.; Tobias-Grasso, C.A.M.; Acharya, A.; Leal, S.M.; Mohlke, K.L.; Mayol, N.L.; Cutiongco-de la Paz, E.M.; Santos-Cortez, R.L.P. The SLC26A4 c.706C >G (p.Leu236Val) variant is a frequent cause of nonsyndromic hearing impairment in Filipino cochlear implantees. Otol. Neurotol. 2018, 39, e726-e730. [CrossRef] [PubMed]

34. Truong, B.T.; Yarza, T.K.L.; Bootpetch Roberts, T.; Roberts, S.; Xu, J.; Steritz, M.J.; Tobias-Grasso, C.A.M.; Azamian, M.; Lalani, S.R.; Mohlke, K.L.; et al. Exome sequencing reveals novel variants and unique allelic spectrum for hearing impairment in Filipino cochlear implantees. Clin. Genet. 2020, 95, 634-636. [CrossRef] [PubMed]

35. Li, H.; Durbin, R. Fast and accurate short read alignment with Burrows-Wheeler transform. Bioinformatics 2009, 25, 1754-1760. [CrossRef]

36. McKenna, A.; Hanna, M.; Banks, E.; Sivachenko, A.; Cibulskis, K.; Kernytsky, A.; Garimella, K.; Altshuler, D.; Gabriel, S.; Daly, M.; et al. The Genome Analysis Toolkit: A MapReduce framework for analyzing next-generation DNA sequencing data. Genome Res. 2010, 20, 1297-1303. [CrossRef]

37. Wang, K.; Li, M.; Hakonarson, H. ANNOVAR: Functional annotation of genetic variants from high-throughput sequencing data. Nucleic Acids Res. 2010, 38, e164. [CrossRef]

38. Schwarz, J.M.; Rodelsperger, C.; Schuelke, M.; Seelow, D. MutationTaster evaluates disease-causing potential of sequence alterations. Nat. Methods 2010, 7, 575-576. [CrossRef]

39. Lek, M.; Karczewski, K.J.; Minikel, E.V.; Samocha, K.E.; Banks, E.; Fennell, T.; O’Donnell-Luria, A.H.; Ware, J.S.; Hill, A.J.; Cummings, B.B.; et al. Analysis of protein-coding genetic variation in 60,706 humans. Nature 2016, 536, 285-291. [CrossRef] [PubMed]

40. Scott, E.M.; Halees, A.; Itan, Y.; Spencer, E.G.; He, Y.; Azab, M.A.; Gabriel, S.B.; Belkadi, A.; Boisson, B.; Abel, L.; et al. Characterization of Greater Middle Eastern genetic variation for enhanced disease gene discovery. Nat. Genet. 2016, 48, 1071-1076. [CrossRef]

41. Kircher, M.; Witten, D.M.; Jain, P.; O’Roak, B.J.; Cooper, G.M.; Shendure, J. A general framework for estimating the relative pathogenicity of human genetic variants. Nat. Genet. 2014, 46, 310-315. [CrossRef] [PubMed]

42. Liu, X.; Jian, X.; Boerwinkle, E. dbNSFP: A lightweight database of human nonsynonymous SNPs and their functional predictions. Hum. Mutat. 2011, 32, 894-899. [CrossRef]

43. GenomeAsia $100 \mathrm{~K}$ Consortium. The GenomeAsia $100 \mathrm{~K}$ Project enables genetic discoveries across Asia. Nature 2019, 576, $106-111$. [CrossRef] [PubMed] 
44. Thorvaldsdottir, H.; Robinson, J.T.; Mesirov, J.P. Integrative Genomics Viewer (IGV): High-performance genomics data visualization and exploration. Brief. Bioinform. 2013, 14, 178-192. [CrossRef] [PubMed]

45. Xiao, S.; Yu, C.; Chou, X.; Yuan, W.; Wang, Y.; Bu, L.; Fu, G.; Qian, M.; Yang, J.; Shi, Y.; et al. Dentinogenesis imperfecta 1 with or without progressive hearing loss is associated with distinct mutations in DSPP. Nat. Genet. 2001, 27, 201-204. [CrossRef] [PubMed]

46. Kim, J.W.; Nam, S.H.; Jang, K.T.; Lee, S.H.; Kim, C.C.; Hahn, S.H.; Hu, J.C.C.; Simmer, J.P. A novel splice acceptor mutation in the DSPP gene causing dentinogenesis imperfecta type II. Hum. Genet. 2004, 115, 248-254. [CrossRef] [PubMed]

47. Li, W.X.; Peng, H.; Yang, L.; Hao, Q.Q.; Sun, W.; Ji, F.; Guo, W.W.; Yang, S.M. Familial nonsyndromic hearing loss with incomplete partition type II by novel DSPP gene mutations. Acta Otolaryngol. 2018, 138, 685-690. [CrossRef] [PubMed]

48. Liu, W.H.; Chang, P.Y.; Chang, S.C.; Lu, J.J.; Wu, C.M. Mutation screening in non-syndromic hearing loss patients with cochlear implantation by massive parallel sequencing in Taiwan. PLoS ONE 2019, 14, e0211261. [CrossRef] [PubMed]

49. Bajoghli, B.; Ramialison, M.; Aghaallaei, N.; Czerny, T.; Wittbrodt, J. Identification of starmaker-like in medaka as a putative target gene of Pax2 in the otic vesicle. Dev. Dyn. 2009, 238, 2860-2866. [CrossRef]

50. Prasad, M.; Zhu, Q.; Sun, Y.; Wang, X.; Kulkarni, A.; Boskey, A.; Feng, J.Q.; Qin, C. Expression of dentin sialophosphoprotein in non-mineralized tissues. J. Histochem. Cytochem. 2011, 59, 1009-1021. [CrossRef]

51. Kruszka, P.; Hu, T.; Hong, S.; Signer, R.; Cogne, B.; Isidor, B.; Mazzola, S.E.; Giltay, J.C.; van Gassen, K.L.I.; England, E.M.; et al. Phenotype delineation of ZNF462 related syndrome. Am. J. Med. Genet. A 2019, 179, 2075-2082. [CrossRef]

52. Helou, J.; Otto, E.A.; Attanasio, M.; Allen, S.J.; Parisi, M.A.; Glass, I.; Utsch, B.; Hashmi, S.; Fazzi, E.; Omran, H.; et al. Mutation analysis of NPHP6/CEP290 in patients with Joubert syndrome and Senior-Loken syndrome. J. Med. Genet. 2007, 44, 657-663. [CrossRef] [PubMed]

53. Wesdorp, M.; de Koning Gans, P.A.M.; Schraders, M.; Oostrik, J.; Huynen, M.A.; Venselaar, H.; Beynon, A.J.; van Gaalen, J.; Piai, V.; Voermans, N.; et al. Heterozygous missense variants of $L M X 1 A$ lead to nonsyndromic hearing impairment and vestibular dysfunction. Hum. Genet. 2018, 137, 389-400. [CrossRef]

54. Schrauwen, I.; Chakchouk, I.; Liaqat, K.; Jan, A.; Nasir, A.; Hussain, S.; Nickerson, D.A.; Bamshad, M.J.; Ullah, A.; Ahmad, W.; et al. A variant in $L M X 1 A$ causes autosomal recessive severe-to-profound hearing impairment. Hum. Genet. 2018, 137, 471-478, [CrossRef] [PubMed]

55. Barat-Houari, M.; Sarrabay, G.; Gatinois, V.; Fabre, A.; Dumont, B.; Genevieve, D.; Touitou, I. Mutation update for COL2A1 gene variants associated with type II collagenopathies. Hum. Mutat. 2016, 37, 7-15. [CrossRef] [PubMed]

56. Steffes, G.; Lorente-Canovas, B.; Pearson, S.; Brooker, R.H.; Spiden, S.; Kiernan, A.E.; Guenet, J.L.; Steel, K.P. Mutanlallemand $(\mathrm{mtl})$ and belly spot and deafness (bsd) are two new mutations of Lmx1a causing severe cochlear and vestibular defects. PLoS ONE 2012, 7, e051065. [CrossRef]

57. Nichols, D.H.; Pauley, S.; Jahan, I.; Beisel, K.W.; Millen, K.J.; Fritzsch, B. Lmx1a is required for segregation of sensory epithelia and normal ear histogenesis and morphogenesis. Cell Tissue Res. 2008, 334, 339-358. [CrossRef]

58. Maddox, B.K.; Garofalo, S.; Horton, W.A.; Richardson, M.D.; Trune, D.R. Craniofacial and otic capsule abnormalities in a transgenic mouse strain with a Col2a1 mutation. J. Craniofac. Genet. Dev. Biol. 1998, 18, 195-201.

59. Happ, H.; Schilter, K.F.; Weh, E.; Reis, L.M.; Semina, E.V. 8q21.11 microdeletion in two patients with syndromic peters anomaly. Am. J. Med. Genet. A 2016, 170, 2471-2475. [CrossRef]

60. Palomares, M.; Delicado, A.; Mansilla, E.; de Torres, M.L.; Vallespin, E.; Fernandez, L.; Martinez-Glex, V.; Garcia-Minaur, S.; Nevado, J.; Santos Simarro, F.; et al. Characterization of a 8q21.11 microdeletion syndrome associated with intellectual disability and a recognizable phenotype. Am. J. Hum. Genet. 2011, 89, 295-301. [CrossRef]

61. Salehi, P.; Ge, M.X.; Gundimeda, U.; Baum, L.M.; Cantu, H.L.; Lavinsky, J.; Tao, L.; Myint, A.; Cruz, C.; Wang, J.; et al. Role of neuropilin-1/semaphoring-3A signaling in the functional and morphological integrity of the cochlea. PLoS Genet. 2017, 13, e1007048. [CrossRef] [PubMed]

62. Liu, F.; Guo, H.; Ou, M.; Hou, X.; Sun, G.; Gong, W.; Jing, H.; Tan, Q.; Xue, W.; Dai, Y.; et al. ARHGAP4 mutated in a Chinese intellectually challenged family. Gene 2016, 578, 205-209. [CrossRef] [PubMed]

63. Huang, L.; Poke, G.; Gecz, J.; Gibson, K. A novel contiguous gene deletion of AVPR2 and ARHGAP4 genes in male dizygotic twins with nephrogenic diabetes insipidus and intellectual disability. Am. J. Med. Genet. A 2012, 158, 2511-2518. [CrossRef]

64. Chen, D.Y.; Liu, X.F.; Lin, X.J.; Zhang, D.; Chai, Y.C.; Yu, D.H.; Sun, C.L.; Wang, X.L.; Zhu, W.D.; Chen, Y.; et al. A dominant variant in DMXL2 is linked to nonsyndromic hearing loss. Genet. Med. 2017, 19, 553-558. [CrossRef]

65. Wonkam-Tingang, E.; Schrauwen, I.; Esoh, K.K.; Bharadwaj, T.; Nouel-Saied, L.M.; Acharya, A.; Nasir, A.; Leal, S.M.; Wonkam, A A novel variant in DMXL2 gene is associated with autosomal dominant non-syndromic hearing impairment (DFNA71) in a Cameroonian family. Exp. Biol. Med. 2021. [CrossRef] [PubMed]

66. Esposito, A.; Falace, A.; Wagner, M.; Gal, M.; Mei, D.; Conti, V.; Pisano, T.; Aprile, D.; Cerullo, M.S.; De Fusco, A.; et al. Biallelic DMXL2 mutations impair autophagy and cause Ohtahara syndrome with progressive course. Brain 2019, 142, $3876-3891$. [CrossRef] [PubMed]

67. Sakuma, N.; Moteki, H.; Azaiez, H.; Booth, K.T.; Takahashi, M.; Arai, Y.; Shearer, A.E.; Sloan, C.M.; Nishio, S.Y.; Kolbe, D.L.; et al. Novel PTPRQ mutations identified in three congenital hearing loss patients with various types of hearing loss. Ann. Otol. Rhinol. Laryngol. 2015, 124, 184S-192S. [CrossRef] 
68. Eisenberger, T.; Di Donato, N.; Decker, C.; Vedove, A.D.; Neuhaus, C.; Nurnberg, G.; Toliat, M.; Nurnberg, P.; Murbe, D.; Bolz, H.J. A C-terminal nonsense mutation links PTPRQ with autosomal-dominant hearing loss, DFNA73. Genet. Med. 2018, $20,614-621$. [CrossRef]

69. Wu, X.; Wang, S.; Chen, S.; Wen, Y.Y.; Liu, B.; Xie, W.; Li, D.; Liu, L.; Huang, X.; Sun, Y.; et al. Autosomal recessive congenital sensorineural hearing loss due to a novel compound heterozygous PTPRQ mutation in a Chinese family. Neural. Plast. 2018, 2018, 9425725. [CrossRef] [PubMed]

70. Van Vierzen, P.B.; Joosten, F.B.; Marres, H.A.; Cremers, C.W.; Ruijs, J.H. Mandibulofacial dysostosis: CT findings of the temporal bones. Eur. J. Radiol. 1995, 21, 53-57. [CrossRef]

71. Guan, Y.; Yang, H.; Yao, X.; Xu, H.; Liu, H.; Tang, X.; Hao, C.; Zhang, X.; Zhao, S.; Ge, W.; et al. Clinical and genetic spectrum of children with primary ciliary dyskinesia in China. Chest 2021. [CrossRef]

72. Blue, E.; Louie, T.L.; Chong, J.X.; Hebbring, S.J.; Barnes, K.C.; Rafaels, N.M.; Knowles, M.R.; Gibson, R.L.; Bamshad, M.J.; Emond, M.J.; et al. Variation in cilia protein genes and progression of lung disease in cystic fibrosis. Ann. Am. Thorac. Soc. 2018, 15, 440-448. [CrossRef]

73. Zheng, Q.Y.; Yan, D.; Ouyang, X.M.; Du, L.L.; Yu, H.; Chang, B.; Johnson, K.R.; Liu, X.Z. Digenic inheritance of deafness caused by mutations in genes encoding cadherin 23 and protocadherin 15 in mice and humans. Hum. Mol. Genet. 2005, 14, 103-111. [CrossRef]

74. Szymko-Bennett, Y.M.; Mastroianni, M.A.; Shotland, L.I.; Davis, J.; Ondrey, F.G.; Balog, J.Z.; Rudy, S.F.; McCullagh, L.; Levy, H.P.; Liberfarb, R.M.; et al. Auditory dysfunction in Stickler syndrome. Arch. Otolaryngol. Head Neck Surg. 2001, 127, 1061-1068. [CrossRef] [PubMed]

75. Bahmad, F.; O'Malley, J.; Tranebjaerg, L.; Merchant, S.N. Histopathology of nonsyndromic autosomal dominant midfrequency sensorineural hearing loss. Otol. Neurotol. 2008, 29, 601-606. [CrossRef] [PubMed]

76. Rodger, C.; Flex, E.; Allison, R.J.; Sanchis-Juan, A.; Hasenahuer, M.A.; Cecchetti, S.; French, C.E.; Edgar, J.R.; Carpentieri, G.; Ciolfi, A.; et al. De novo VPS4A mutations cause multisystem disease with abnormal neurodevelopment. Am. J. Hum. Genet. 2020, 107, 1129-1148. [CrossRef]

77. Delpire, E.; Lu, J.; England, R.; Dull, C.; Thorne, T. Deafness and imbalance associated with inactivation of the secretory Na-K-2Cl co-transporter. Nat. Genet. 1999, 22, 192-195. [CrossRef] [PubMed]

78. Diaz, R.C.; Vazquez, A.E.; Dou, H.; Wei, D.; Cardell, E.L.; Lingrel, J.; Shull, G.E.; Doyle, K.J.; Yamoah, E.N. Conservation of hearing by simultaneous mutation of Na,K-ATPase and NKCC1. J. Assoc. Res. Otolaryngol. 2007, 8, 422-434. [CrossRef] [PubMed]

79. Kenna, M.A.; Irace, A.L.; Strychowsky, J.E.; Kawai, K.; Barrett, D.; Manganella, J.; Cunningham, M.J. Otolaryngologic manifestations of Klippel-Feil syndrome in children. JAMA Otolaryngol. Head Neck Surg. 2018, 144, 238-243. [CrossRef] [PubMed]

80. Yildirim, N.; Arslanoglu, A.; Mahirogullari, M.; Sahan, M.; Ozkan, H. Klippel-Feil syndrome and associated ear anomalies. Am. J. Otolaryngol. 2008, 29, 319-325. [CrossRef]

81. Belfield, J.C.; Witana, J.S.; Connolly, D.J.A. Melnick-Needles syndrome: Report of a case associated with bilateral hypoplasia of the cochlea. AJNR Am. J. Neuroradiol. 2007, 28, 1160-1161. [CrossRef]

82. Swols, D.M.; Foster, J., 2nd; Tekin, M. KBG syndrome. Orphanet. J. Rare Dis. 2017, 12, 183. [CrossRef] [PubMed]

83. Sineni, C.J.; Yildirim-Baylan, M.; Guo, S.; Camarena, V.; Wang, G.; Tokgoz-Yilmaz, S.; Duman, D.; Bademci, G.; Tekin, M. A truncating CLDN9 variant is associated with autosomal recessive nonsyndromic hearing loss. Hum. Genet. 2019, 138, 1071-1075. [CrossRef]

84. Nakano, Y.; Kim, S.H.; Sanneman, J.D.; Zhang, Y.; Smith, R.J.H.; Marcus, D.C.; Wangemann, P.; Nessler, R.A.; Banfi, B. A claudin-9-based ion permeability barrier is essential for hearing. PLoS Genet. 2009, 5, e1000610. [CrossRef] [PubMed]

85. Pang, Z.; Zuo, J.; Morgan, J.I. Cbln3, a novel member of the precerebellin family that binds specifically to Cbln1. J. Neurosci. 2000, 20, 6333-6339. [CrossRef] [PubMed]

86. Schneeberger, P.E.; Kortum, F.; Korenke, G.C.; Alawi, M.; Santer, R.; Woidy, M.; Buhas, D.; Fox, S.; Juusola, J.; Alfadhel, M.; et al. Biallelic MADD variants cause a phenotypic spectrum ranging from developmental delay to a multisystem disorder. Brain 2020, 143, 2437-2453. [CrossRef]

87. Winata, S.; Arhya, I.N.; Moeljopawiro, S.; Hinnant, J.T.; Liang, Y.; Friedman, T.B.; Asher, J.H., Jr. Congenital non-syndromal autosomal recessive deafness in Bengkala, an isolated Balinese village. J. Med. Genet. 1995, 32, 336-343. [CrossRef] [PubMed]

88. Santos-Cortez, R.L.P.; Reyes-Quintos, M.R.T.; Tantoco, M.L.C.; Abbe, I.; Llanes, E.G.D.V.; Ajami, N.J.; Hutchinson, D.S.; Petrosino, J.F.; Padilla, C.D.; Villarta, R.L., Jr.; et al. Genetic and environmental determinants of otitis media in an indigenous Filipino population. Otolaryngol. Head Neck Surg. 2016, 155, 856-862. [CrossRef] [PubMed]

89. Sanchez-Navarro, I.; da Silva, L.R.J.; Blanco-Kelly, F.; Zurita, O.; Sanchez-Bolivar, N.; Villaverde, C.; Lopez-Molina, M.I.; GarciaSandoval, B.; Tahsin-Swafiri, S.; Minguez, P.; et al. Combining targeted panel-based resequencing and copy-number variation analysis for the diagnosis of inherited syndromic retinopathies and associated ciliopathies. Sci. Rep. 2018, 8, 5285. [CrossRef]

90. Rehman, A.U.; Santos-Cortez, R.L.P.; Drummond, M.C.; Shahzad, M.; Lee, K.; Morell, R.J.; Ansar, M.; Jan, A.; Wang, X.; Aziz, A.; et al. Challenges and solutions for gene identification in the presence of familial locus heterogeneity. Eur. J. Hum. Genet. 2015, 23, 1207-1215. [CrossRef] 